\title{
AMP EN ROEPING
}

\author{
PROF. DR. A. D. PONT
}

Die laaste dekade en ' $n$ half het 'n voortgaande diskussie oor die amp in die kerk na vore gebring. Verskillende gebeurtenisse en situasies binne die kerk het dan op die een en dan weer op ' $n$ ander aspek van die amp die klem laat val. Telkemale het dit geblyk dat, afgesien van lofwaardige uitsonderings, daar leemtes bestaan in die kennis van die inhoud, wese en plek van die amp in die reformatorieseteologie en kerkinrigting.

Dit was egter nie ' $n$ saak wat net tot ons kerk of vaderland beperk was nie want verskillende kerke, kerklike instansies en skrywers het deur middel van rapporte, memoranda en publikasies hernude aandag aan die amp in die kerk gegee. Hierdie diskussie, hier en elders, is nog steeds nie afgesluit nie en voortgaande besinning en navorsing blyk nog voortdurend nodig te wees.

Met hierdie geleentheid waar prof. dr. B. J. Engelbrecht gehuldig word vanweë sy dienswerk ter wille van kerk en teologie gedurende die afgelope vyf en twintig jaar, is gevoel dat enkele opmerkings oor die tema amp en roeping gemaak kan word. Dit omdat prof. Engelbrecht ook sy bydrae in hierdie besinning en diskussie gelewer het. Op hierdie wyse wil ons prof. Engelbrecht op tasbare wyse eer en ook dank betuig vir die negentien jaar wat ons nou al saam met hom spesifiek in die teologiese fakulteit en op die terrein van die teologie kon arbei.

Wanneer oor die tema amp en roeping binne die konteks van ons kerk gehandel word, dan is dit 'n primêre noodsaaklikheid om weer 'n oomblik na te gaan wat die reformatoriese vadere, in breë trekke, onder die begrippe amp en roeping verstaan het. Uit die aard van die saak sal dit nie moontlik wees om hier 'n volledige ampsteologie uit te werk nie. Waar die begrippe amp en roeping so nou aan mekaar verbind is in die reformatoriese verstaan van die amp, is dit moontlik om enkele sake wat tog van gewig is vir die huidige diskussie weer na vore te haal. Immers in die huidige diskussie word dikwels nagelaat om voldoende rekening te hou met die fundamentele arbeid wat die reformatoriese vadere in hierdie verband gedoen het. Terselfdertyd word die kardinale voorwaardes wat Johannes Calvyn vir die toetrede tot die amp gestel het ook te veel op die agtergrond gelaat. Calvyn het gestel dat die kandidaat tot die amp 'n suiwer leer moes aanhang en verkondig. Dit wil sê sy leer moet in alles ooreenkom met die Woord van God, die Heilige Skrif. Nie die ideologieë van hierdie wêreld nie, nie die filosofieë van die buitekerklike tydgenote nie, nie die soslologese of psigologiese wyshede van teoretiserende akademici moet as voorwaardelike kennis vir die toekomstige dienaar van die Woord gesien word nie maar primêr én sekondêr die kennis van en die geloof in die 
suiwere Woord van God. Daardie kennis van die Woord van God moet aangevul word deur die integere lewenswandel, die vrome (ewensstyl. ${ }^{\text {1) }}$

Juis in ons dae, met sy sterk materialistiese inslag en die sterk sekulariserende tendense wat in die hand gewerk word deur die ideologieë wat al meer geeste gevange neem, ook in die kerk, is dit miskien nodig dat wéér besef moet word dat die openbare amp in die kerk sulke hoë eise stel omdat dit primêr 'n roeping van God is.

Daarom kan die visie van die reformatoriese vadere nie uit die oog verloor word nie omdat hulle juis teenoor die verworde, verwêreldlikte amp van die Roomse kerk getrag het om die suiwer Skriftuurlike maatstawwe weer na vore te bring. So skerp het die reformatoriese vadere van die Roomse kerk verskil dat uiteindelik van die papale kerkregeringsisteem en die Roomse ampsopvatting niks oorgebly het in die kerke van die hervorming nie.

As die Roomse ampsopvatting in sy grondtrekke nagegaan word, dan is dit duidelik dat dit in die Decretum pro Armenis van die Konsilie van Florence, 1431-1447, sy beslag gekry het. ${ }^{2}$ ) Hiervolgens word die amp vasgeknoop aan die sakramenet van die mis, ${ }^{3}$ ) en met die ordening ontvang die ampsdraer ' $n$ vermeerdering van genade sodat hy 'n bekwame dienaar sal wees. Die verbintenis van die amp met die altaarsakrament skenk aan die Roomse ampsdraer 'n besondere gesag. ${ }^{4}$ ) Dit word dan verder versterk deur die feit dat die sakrament vandie wyding die ampsdraer in die besondere geestelike stand verhef waaruit hy nooit meer kan val nie. 'n Derde faktor wat aan die Roomse amp 'n besondere magsposisie verleen, is die beklemtoning van die objektief-instrumentele karakter van die amp. Juis hierdie opvatting maak die verwording van die amp wat in die vyftiende en sestiende eeu so duidelik sigbaar word, moontlik. Hierdie ampsopvatting bring dan mee dat die amp gesien word as een manier waardeur die voortgesette heilshandelinge van God aan die mens meegedeel word.

So het die amp van dienaar (diakonos) in die Roomse kerk 'n heersersamp geword wat uitgaan van die pretensie dat die amp beskik oor die moontlikheid om die heil en die genade van God aan die mens mee te deel. In die Roomse kerk het die amp 'n statiese en

1) Joh. Calvinus, Comm. Eks. 28:4 asook sy Institutio christianae religionis, 1559 , IV. 3. 12 waar sprake is van 'n heilige lewenswandel.

2) H. Denzinger, Enchiridio Symbolorum, Roma etc. 1957, 701 p. 258. Dit kom voor in die bul Exultate Deo van 22. 11. 1439. Sien ook Conciliorum Oecumenicorum Decreta, Roma etc. 1957. p. 525.

3) Die forma van die priesterskap is die woorde: Accipe potestatem offerendi sacrificium in ecclesia pro vivis et mortuis, in nomine Patris en Filii et Spiritus Sancti.

H. Denzinger, l.c., p. 259.

4) Vgl. in hierdie verband $W$. van 't Spijker, De Ambten bij Martin Bucer, Kampen 1970, bl. 16 wat hierdie saak uitvoerig beredeneer. Hy wys o.a. daarop dat Thomas Aquinas hier onderskei in 'n potestas ordinis wat die bevoegdheid verleen om die sakrament te bedien en ' $n$ protestas iurisdictionis wat saam hang met die sleutelmag van die kerk. 
hooghartige heersersamp geword waar die ampsdraer ver bo die gewone gelowige verhef is termyl die amp ex opere operato funksioneer afgesien van die kwaliteite of opvattings van die ampsdraer self.

Die Roomse amp kan ook gekarakteriseer word as 'n persoonlike privilege wat ' $n$ mens verwerf terwyl die amp ook gesien word as volkome selfgenoegsaam. ' $n$ Volledige ampsbediening is immers moontlik wanneer die Roomse ampsdraer hom slegs met die koorgebed en die opdra van privaatmisse besig hou. So is die amp losgemaak van 'n positiewe diens in die kerk ter wille van die Woordverkondiging of die toerusting van die gelowiges vir hulle dienswerk (Ef. 4:11-12). So word daar die ampsdraer belangriker as die amp want hy ontvang die character indelibilis en omdat die amp ex opere operato funksioneer, kan die kwaliteit van die ampsdraer self nie meer die funksie van die amp $\mathrm{nl}$. die meedeling van genade beinvloed nie. Waartoe dit alles gelei het, kan byvoorbeeld nog steeds nagelees word in Erasmus se bekende Laus Stultitiae (1509).

Verder word in die Roomse ampsopvatting die amp onlosmaaklik vasgeknoop aan die kerk as heilsinstituut. Die amp word die onfeilbare funksie van die kerk wat die sigbare liggaam van Christus op aarde is. Kerk en amp word die middels waardeur onfeilbaar die heilsgenade aan die mens meegedeel word en waardeur die sondaar na die ewige heil gelei word. Die lidmaat, as onmondige, is volkome van die ampsdraer en die kerk afhanklik as hy die saligheid wil ontvang.

Dit is teen hierdie ampsopvatting, waarvan slegs die grondtrekke geteken is, dat die reformatoriese vadere ook in opstand kom. Dit is duidelik dat die hele Roomse opvatting hartgrondig verwerp word. As Luther en na hom die ander reformatore, oor die amp besin dan geskied dit vanuit die Skrif alleen in ' $n$ poging om die amp weer volkome Bybels te fundeer. So beteken die kerkhervorming óók ' $n$ omvattende hervorming van die amp.

Die baanbrekende vernuwing ten opsigte van die amp word deur Martin Luther gedoen. Al die reformatore wat na Luther oor die amp handel, aanvaar die breë grondlyne wat hy getrek het en in baie opsigte is hulle opvatting oor die amp ' $n$ verwerking en soms net ' $n$ nadere presiesering van wat Luther, op grond van die Skrif alleen, reeds geleer het.

Luther se teologie kom voort uit sy sentrale stelling van die regverdiging van die gelowige sola gratia, sola fide propter Christum. Die evangelie is dié middel waardeur die regverdigende genade van God in Christus aan die mens meegedeel word en daarom is die evangelie die verus thesaurus ecclesiae. ${ }^{5}$ ) Die evangelie is die grond én die moontlikheid vir die regverdiging van die sondaar en daarom kan nóg die mens nóg die kerk sonder die Woord van God bestaan.

5) M. Luther, Disputatio pro declaratione virtutis indulgentianum, 1517, art. 62. 
Die Woord is ten opsigte van die kerk van konstituerende belang. Die verkondiging, prediking, bekendmaking van die evangelie is dié middel wat God gebruik in die regverdiging van die sondaar. Deur die prediking vind die heilshandeling van God met die mens plaas. So kan gesê word dat vir Luther die heil van die mens en die bestaan van die kerk aan die Woord van God verbind is. Dit bring vanself die diens aan die Woord, die ministerium verbi na vore. Sowel die sola gratia as die sola fide van die regverdigingsleer maak die diens aan die Woord noodsaaklik. Soos Luther dit stel ${ }^{6}$ )

„.... sey gewis, das Gott kein ander weise hat noch haben wil, die sunde zuvergeben, denn dürch das mündliche Wort, so er uns menschen befohlen hat, wenn du die vergebung nicht ym wort suchst, das sie Gott hingelegt hat, so wirstu vergebens gen himel nach der gnade gaffen."

Hierdie noodsaaklikheid, wat vir Luther deel van God se heilsorde is, bring mee dat Luther die amp primêr as 'n funksionele amp sien. ${ }^{7}$ ) Die amp is by Luther nooit ' $n$ heerskappy of ' $n$ besondere voorreg nie maar 'n dienswerk wat in die kerk ter wille van die gelowiges uitgevoer moet word. Die ampsopdrag is 'n opdrag wat 'n gelowige van God self ontvang en die opdrag is om God se werk in die wêreld te doen. Die ampsdraer word dus nie tot heerskappy oor die ander gelowiges geroep nie maar hy word geroep om deur sy dienswerk die heerskappy van God in die gemeente én die wêreld te verwerklik.

Hierdie gedagte het Luther baie sterk na vore gebring in sy Lesings oor die Brief aan die Romeine uit die jare 1515-1516.8) Met verwysing na vs. 1 waar Paulus homself aandui as servus Jesu Christi stel Luther dat servus ' $n$ ampstitel is. Daarom sien hy dit nie alleen as ' $n$ aanduiding van Paulus se onderwerping aan God alleen nie maar dat Paulus hiermee bedoel dat hy sy amp van God ter wille van die mense ontvang het. As Paulus leer, preek, doop en ander werke doen, wat eintlik God se werk is, dan doen hy dit nie as ' $n$ heerser of ' $n$ magtige figuur nie maar as 'n dienskneg. Hier lê Luther dan die stel reël neer: die ampsdraer dien nie omdat hy tot heerskappy geroep is nie, maar hy heers in so ver as wat hy dien. Ampswerk is dienswerk, amp is diens ter wille van ander.

In sy stryd met Rome verwyt Luther die Roomse kerk dat laasgenoemde die charitatis ministerium in ' $n$ iurisdictio verander het en daarmee is die amp verhef bo die kerk ên bo die evangelie. Die amp is egter niks anders as ' $n$ opdrag om die evangelie te verkondig nie en assodanig is dit ' $n$ dienswerk in die kerk ter wille van die kerk. ${ }^{\theta}$ )

6) Vgl. O. Clemen, Luthers Werke in Auswahl, Berlin 1963, Bd. VII, S. 243.

7) Vgl. Hellmut Lieberg. Amt und Ordination bei Luther und Melanchton, Göttingen 1962, S. 19-24.

8) O. Clemen, a.a.O., Bd. V. S. 222 f.

๑) W. Stein, Das Kirchliche Amt bei Luther, Wiesbaden 1974, S. 216. 
Juis om die dienskarakter van die amp te beklemtoon, herhaal Luther dat, volgens sy verstaan van die N.T. daar net één amp in die kerk is en dat enige vorm van hiërargie nie Skriftuurlik is nie maar suiwer menslike ordening is. ${ }^{10}$ ) Daarby kom sy verwerping, in 1520 , van die gedagte dat die ordening tot die amp 'n sakrament sou wees. Die amp is en bly niks meer nie as ' $n$ opdrag tot ' $n$ bepaalde dienswerk. Dit is dan verder ' $n$ dienswerk waartoe God die dienaar self roep en deur sy dienswerk wil God die gelowiges en die kerk opbou. Die amp is dus nié 'n amp van die kerk nie maar 'n gawe van God aan die kerk (Ef. 4:11-12).

Vir Luther is dit duidelik dat die amp ook 'n goddelike karakter dra. Die ampsopdrag is deur God sélf gegee en ook die amp self, dit wil sê die uitoefening van die ampsopdrag deur bepaalde, geroepe mense, is deur Christus self ingestel. Die ampsdraer self wat hierdie ampsopdrag, wat deur God gegee is, uitvoer doen dit met die gesag van die Heer van die kerk want deur die ministerium verbi et sacramentorum handel Christus self regverdigend en verlossend met sy gemeente en die wêreld. Hierdie goddelike karakter eis van die ampsdraer ' $n$ duidelike gehoorsaamheid teenoor sy ampsopdrag én die Heer van die kerk. Terselfdertyd vorm hierdie gehoorsaamheid ook die vaste, objektiewe agtergrond vir die amp wat dit van menslike willekeur behoort te vrywaar.

By Philippus Melanchton, die eerste sistematikus van die Lutherse teologie, lê daar hier en daar ' $n$ ander aksent. Melanchton plaas amp en kerk weer in ' $n$ noue samehang en wil die een nie los van die ander sien nie. Hy omskryf die kerk as 'n coetus vocatorum en dan in dié sin dat deur die verkondiging van die evangelie en die bediening van die sakramente, waarin die Heilige Gees werksaam is, die coetus van gelowiges saamgeroep word.

'n Belangrike stelling van Melanchton is dat die evangelie, die roeping tot die geloof, vooráf gaan aan die vorming van gemeente en kerk. God versamel sy kerk deur die evangelie en die sakramente en daarom het die evangelie hier 'n prioriteit want die kerk word deur die evangelie byeengeroep, versorg en regeer. Net soos die Heilige Gees nie anders as deur die verkondigde Woord en die sakrament wat in die openbaar bedien word, funksioneer nie so kan die kerk alleen deur die Woord en die sakrament ontstaan en voortbestaan. ${ }^{11}$ )

10) Dié gedagte werk Luther veral uit in sy Kommentaar op Galate van 1519.

11) H. Lieberg, a.a.O., S. 250-253. 
Daarom is vir Melanchton Woord- en sakramentsbediening onlosmaaklik aan die amp verbind. In sy Johanneskommentaar (1536) stel hy dit so: ${ }^{12}$ )

„Sit ergo haec definitio Ecclesiae visibilis, Ecclesia est coetus amplectentium Evangelium, et societate sacramentorum et ministerii evangelici coniunctorum, ac renatorum per Spiritum sanctum."

Daarom sê Melanchton selfs dat nie net dieselfde evangelie nie maar ook dieselfde amp die norm vir ware eenheid van die kerk is en in 1552 noem hy selfs die amp wanneer hy die notae ecclesiae as volg aandui: ${ }^{13}$ )

„1. Consensus in doctrina Evangelii incorrupta, scilicet in fundamento;

2. Legitimus usus Sacramentorum;

3. Obedientia Ministerio debita iuxta Evangelium."

So word by Melanchton die amp genoem onder die kenmerke van die ware kerk en sien hy die amp as ' $n$ instelling van God ten behoewe van die kerk. Die amp is die middel waardeur God sy genade-aanbod, soos gegee in die evangelie, in die wêreld laat uitdra. Daarom is dit die taak van die amp om die mense tot Christus te roep en so, uit die mensgeslag, 'n kerk rondom Woord en sakrament te versamel. Die amp is dus ' $n$ gawe van God tot opbou van die kerk en Melanchton stel dat die hoofinhoud van die amp is: ministerium docendi Evangelium et administrandi Sacramenta.

As openbare amp, wat saamhang met die feit dat die evangelie in die openbaar verkondig moet word, is die amp die middel wat God gebruik om die kerk in die openbaar te vestig. Die amp word dus nie uit ' $n$ menslike of ' $n$ sosiologiese behoefte gebore nie maar dit gaan onmiddellik terug op die wil van God, die amp is institutum Dei. Dit wil sê 'n ministerium divinitus ordinatum en assodanig ' $n$ sanctissimum mnsterum. ${ }^{14}$ ) Daarom betrek Melanchton Joh. 20:21 "Soos die Vader My gestuur het, stuur Ek julle ook", op alle ampsdraers en lei daaruit af dat met hierdie woord Christus die amp vir alle tye ten behoewe van die kerk ingestel het. Die amp het dus voortgespruit uit die apostelamp en is vir Melanchton apostoliese amp. Dié amp word deur mense gedra wat daartoe deur God geroep is en deur die kerk beroep is om so die openbare diens van God in stand te hou waardeur die kerk rondom die evangelie versamel en so

12) H. Lieberg, a.a.O., S. 255.

13 H. Lieberg, a.a.0., S. 257.

14) Hierdie standpunt het Melanchton duidelik gestel in die Confessio Augustana, art. 5.1: Solchen Glauben zu erlangen, hat Gott das Predigtamt eingesetzt, Evangelium und Sakrament geben... 
opgebou word. ${ }^{15}$ ) Die amp is ' $n$ instrument waardeur God self, deur Woord en sakrament, sy heilshandelinge met die mens voltrek. Net soos Melanchton, laat die Straatsburgse hervormer, Martin Bucer, sy opvatting oor die amp bepaal deur die ekklesiologie. ${ }^{16}$ ) Alleen as daar duidelikheid is oor die vraag wat die kerk is, stel Bucer, kan die amp reg verstaan word. ${ }^{17}$ ) In Bucer se denke oor die kerk gebruik hy veral die Pauliniese beeld dat die kerk die liggaam van Christus is om dan baie sterk klem te lê op die feit dat Christus die enige hoof van sy liggaam is, dat $\mathrm{Hy}$ die koning van die kerk is. Dit beteken dan verder dat alle lede van die kerk primêr aan Christus gehoorsaamheid verskuldig is. Die kerk self is dan die communio sanctorum waar die geloof beleef en uitgeleef moet word. ${ }^{18}$ )

Wanneer Bucer nou handel oor die amp dan is daar by hom 'n dubbele motief. In die eerste plek is die amp 'n charisma in die communio sanctorum en andersyds is die amp missio Christi. As Bucer die amp en die communio sanctorum nou aan mekaar verbind dan hang dit saam met die feit dat hy die priesterskap van die gelowiges beklemtoon. Die taak van elke gelowige is basies dieselfde as die opdrag aan die amp. Die publieke amp is egter daar om hierdie diens van die broederskap binne die kerk te bevorder. ${ }^{19}$ ) Uit die communio sanctorum word sommige geroep tot die ministerium publicum wat egter nie die priesterskap van die gelowiges onnodig maak nie. ${ }^{20}$ )

Uitgaande van die N.T. stelling dat daar 'n verskeidenheid van genadegawes is, onderskei Bucer nie alleen tussen die algemene priesterskap van alle gelowiges en die publieke amp nie maar sien hy ook ' $n$ verskeidenheid binne die amp. ${ }^{21}$ ) By Bucer is daar dus ' $n$ permanente korrelasie tussen gemeente en amp wat gegrond is in 'n pneumatiese medewerking in die liggaam van Christus. ${ }^{22}$ )

15) Hiervoor beroep hy hom veral op Tit. 1:5 en Ef. 4:8 vg.

16) Bucer is van belang in hierdie opsig nie alleen omdat hy, wat self uit die Lutherse hervorming voortgekom het, 'n soort brugfiguur na die Switserse hervormers was nie maar ook omdat hy in 'n sekere sin as 'n leermeester van Calvyn beskou kan word. Hoe nou Calvyn byvoorbeeld aansluit by Bucer word aangetoon deur $W$. van 't Spijker, Prädestination bei Bucer und Calvin, art. in Calvinus Theologus, Neukirchen-Vluyn 1976, S. 85: In mancher Hinsicht herrschat grosze Uebereinstimmung zwischen der Ansichten beiden Reformatoren. Im Hinblick auf die kirchlichen Aemter, die Seelsorge, die Liturgie und die notwendige Kirchenordnung, aber auch was die Ausübung der kirchlichen Zucht betrafft, lässt sich deutlich der Einflusz Bucers auf Calvin nachweisen.

17) W. van 't Spijker, De Ambten bij Martin Bucer, bl. 328.

18) Bucer se ekklesiologie is veral te vinde in sy De vi et usu sacri ministerii, 1550-1551 en sy De regno Christi, 1550.

19) W. van 't Spijker, a.w., bl. 343.

20) W. van 't Spijker, a.w., bl. 347: ... het kerkelijk ambt dient om het priesterschap der gelovigen te activeren, het is door de Here ingesteld, en zij die ertoe geroepen worden ontvangen van Hem de bekwaamheid om het tot heil van de kerken uit te oefenen.

21) W. van 't Spijker, a.w., bl. 357-358.

22) W. van 't Spijker, a.w., bl. 349: De kerkelijke ambtsdrager is een door de Geest bekwaamd en toegerust persoon, een charismaticus, die als zodanig door Christus wordt gebruikt in zijn ministerium. Zijn dienst is, naar de wonderlijke orde des heils, dienst van Christus. 
Die tweede aspek van Bucer se ampsopvatting is dat die amp in die gemeente ' $n$ instelling van Christus is. Christus verleen sy gawes aan die gemeente per ministeria quae ad ipsum instituit..23) Christus self, as hoof en koning van sy kerk, is self minister omdat Hy nie sy eie nie maar die wil van die Vader in alles doen. Deur die Heilige Gees voltrek Christus sy dienswerk.

In sy De vi et usu sacra ministerii wys Bucer nou twee uiterstes ten opsigte van die amp af. Dié uiterstes is altyd moontlik omdat God die risiko loop om sy heil aan mense deur middel van mense te gee. Aan die een kant is dit moontlik om die amp te verabsoluteer sodat dit nie meer gesien word as ' $n$ ministerium Christi nie. Dan word die amp, soos in die Roomse kerk, 'n magisterium van die priesters. Aan die ander kant kan die genade van God weer so verabsoluteer word dat die amp, as uiterlike saak, heeltemal verwerp word. Dié moontlikhede is daar omdat die mens nie altyd wil glo en begryp dat God self deur die amp of diens van mense met mense werk om hulle so die ewige hell te gee nie. Vir Bucer bly dit vas staan dat God self, deur die diens van die amp, in die wêreld werksaam is. In daardie $\sin$ is die amp nie net ' $n$ middel in Gods hand nie maar is die ampsdraer ook 'n medewerker van God. 'n Voorwaarde bly dan dat die dienskneggestalte van die amp nooit geskend sal word nie. ${ }^{24}$ )

Omdat die amp ' $n$ ministerium Christi is, is die absolute binding aan die Woord noodsaaklik en hierin lê die enigste gesag van die ampsdraer. Die gesag van die ampsdraer is die gesag van die Woord. Die verbondenheid van die ampsdraer aan die gemeente mag nooit die verbondenheid aan Christus en sy ministerium verbreek nie. Andersyds staan die ampsdraer nooit bo of teenoor die gemeente nie. Amp en gemeente is beide gebind aan die Woord en altwee moet daarvoor buig. Daarom eis die gemeente dat die ampsdraer hom aan die Woord sal hou, andersyds moet die ampsdraer toesien dat die Woord oor die hele lewe van die gemeente heerskappy sal voer.

Let ons op die opvattings van die kerkvader Johannes Calvyn dan val dit op dat hy, net soos Melanchton en Bucer, sy opvattings oor die amp verbind met die ekklesiologoie. Hier gaan dit vir Calvyn spesifiek oor die orde waardeur die heer van die kerk wil hê dat sy kerk bestuur sal word. ${ }^{25}$ ) Die regering van die kerk is in die lig van

23) Brief van Bucer aan à Lasco, aangehaal by W. van 't Spijker, a.w., bl. 349.

24) W. van 't S.pijker, a.w., bl. 355 siteer Bucer as volg: Wij moeten het ambt hoogachten, maar zooals Christus het bevolen heeft. Wij moeten de ambtsdrager en zijn dienst erkennen als dienaar en dienst van Christus, en er ijverig gebruik van maken, tot God opziende in waar geloof en bekering, in de stellige overtuiging dat $\mathrm{Hij}$ zijn gaven niet verleent aan de hoogmoedigen en aan de verachters van de orde, die $\mathrm{Hij}$ instelde tot liefde en wederzijdse samenbinding en tot vernedering van de menselijke hoogmoed. Slechts dient de bepaling in acht genomen te worden, dat er een passend onderscheid is tusschen de dienaar en de meester, tussen dienst en meesterschap. 
die feit dat Jesus Christus die enigste hoof en heer van sy kerk is, nié 'n menslike reëling nie maar ordinatio Dei. Dit wil nou nie sê dat elke faset en onderdeel van die kerkregering deur God self bepaal of neergelê is nie maar dat die essensiële van die kerkregering ordinatio Dei is. ${ }^{26}$ ) Dié essensiële sien Calvyn o.a. in die goddelike instelling van die amp van dienaars van die Woord in wie se hande die regering van die kerk gelê word. ${ }^{27}$ ) Die herder of dienaar van die Woord doen God se eie werk, soos hy dit stel: ${ }^{28}$ )

„Hierdie werk is dan die opbou van die kerk, die ewige saligheid van die mense, die herstel van die wêreld en, kort gesê, die herstel van die koninkryk van God en Christus. Die uitnemendheid en waardigheid van hierdie taak kan nie na waarde geskat word nie." want $^{29}$ )

In die lig sien Calvyn dan die herder as 'n vader van die kerk „die kerk van God word nie alleen in die lewe geroep deur die heilige en vrome herders nie maar... die lewe van die kerk word ook deur hulle bewaar, gevoed en bevestig tot die einde toe."

Omdat Calvyn besef dat hierdie hoë aansien wat hy aan die amp verleen maklik kan meebring dat die ampsdraer hom bo die ander gelowiges en lidmate kan verhef, beklemtoon hy weer aan die ander kant dat die gesag in die amp geleë is en nie aan die persoon van die ampsdraer verbind is nie. Soos hy dit stel: ${ }^{30}$ )

"Daarom moet hier onthou word dat alle gesag en waardigheid wat die Heilige Gees, volgens die Skrif, of aan die priesters of aan die profete of aan die apostels of aan die opvolgers van die apostels toeken, in sy geheel eintlik nie aan die mens self gegee word nie maar aan die dienswerk (=amp) waarin hulle gestel is. Of om dit duideliker te sê: aan die Woord waarvan die bediening aan hulle toevertrou is."

25) Joh. Calvinus, Inst. IV. 3. 1.

26) Joh. Calvinus, Comm. Heb. 5:4 en Num. 17:4: Die hele regering van die kerk is so volkome afhanklik van God se wil dat die mens nie toegelaat is om daar in te meng nie.

27) Joh. Calvinus, Comm. Jes. 62:7: Dit behoort uitsluitlik tot die bevoegdheid van God om herders aan te stel.

Vgl. ook Comm. Joh. 20:23: Herders word deur God aangestel om ons ewige saligheid te waarborg.

28) Joh. Calvinus, Comm. I Thess. 5:12.

29) Joh. Calvinus, Comm. I Thess. 2:11: die kerk van God word nie alleen in die lewe geroep deur heilige en vrome herders nie maar... die lewe van die kerk word ook deur hulle bewaar, gevoed en bevestig tot die einde toe.

30) Joh. Calvinus, Inst. IV. 8. 2. 
Om dus herder of ampsdraer te wees, beteken niks anders nie as om ' $n$ gehoorsame dienaar van die Woord te wees nie en beslis nie een of ander kerklike gesagsfiguur wat die Woord, na eie insig, hanteer nie. Om dienaar van die waarheid te wees, beteken om self resloos aan daardie waarheid onderworpe te wees. Alleen hy is werklik 'n dienaar van God wat gehoorsaam én getrou die amp vervul wat aan hom toevertrou is, en wat nie die amp misbruik of vir sy eie doeleindes gebruik nie.

Herhaaldelik beklemtoon Calvyn dit dat die herder dienaar van die Woord is en dit beteken primêr dienaar van Jesus Christus en daarom ook dienaar van die gemeente, die gelowiges, die kerk. Die ampsdraer moet sy dienswerk ten alle tye so verrig dat dit duidelik is dat Jesus Christus die enigste herder, biskop en leraar in en van die kerk is. ${ }^{31}$ ) Die ampsdraer is maar net ' $n$ middel, ' $n$ instrument wat Jesus Christus, die hoof en heer van die kerk gebruik om sy wil te volvoer. Daarom is die amp by Calvyn altyd funksionele amp en nie ' $n$ gesag, ' $n$ waardigheid, ' $n$ privilege wat die ampsdraer in eie reg sou besit of van die kerk sou kan ontvang nie.

Dit is interessant om daarop te let dat Calvyn dit nie daarby laat nie. Die effektiwiteit van die ampsdraer se dienswerk word nie net bepaal deur die feit dat die amp 'n ordinatio Dei is nie maar ook deur die werk van die Heilige Gees.

„Die dienaars van die Woord, so het ek reeds aanvaar, word assistente van God (coadiutores - I Kor. 3:9) genoem omdat $\mathrm{Hy}$ van hulle dienswerk gebruik maak. Maar ons behoort te verstaan dat die dienaars geen mag het bo en behalwe wat Christus verleen nie en dat deur die plant en water gee hulle niks blywends kan doen nie tensy die groeikrag deur die verborge werking van die Gees gegee word nie." ${ }^{.32}$ )

Andermaal word dit duidelik dat die ampsdraer self verdwyn of behoort te verdwyn in die amp. Hoewel die amp ordinatio Dei is, word die effektiwiteit van die dienswerk nie bepaal deur die mens nie maar deur God, die Heilige Gees. Omdat die amp dan so ' $n$ middel in die hand van God is, daarom kan dit die gebroke orde weer herstel, die vergiffenis van die sonde meedeel en die kerk weer opbou.

31) Joh. Calvinus, Inst. IV. 3. 1: Jesus Christus moet alleen in die kerk heers en regeer, in die kerk moet $\mathrm{Hy}$ die leiding hê en die hoogste gesag beklee. Hierdie heerskappy word alleen deur sy Woord uitgeoefen en bedien. Omdat Jesus Christus nie meer sigbaar onder ons teenwoordig is nie om in eie persoon mondeling sy wil aan ons oor te dra, daarom gebruik Christus, soos ons gesê het, die diens van mense om dit alles te doen. Hy doen dit dus deur hierdie plaasvervangende werksaamheid. Daarmee dra Christus nie sy reg en eer oor aan hierdie dienaars nie maar volbring sy eie werk deur hulle mond, net soos ' $n$ ambagsman, om sy werk te doen, gereedskap gebruik.

32) Joh. Calvinus, Cormm. Mk. 16:20 en Hand. 5:9. 
As dit kortliks 'n weergawe was van die sentrale momente van die amp soos die reformatore dit, in die lig van die Heilige Skrif, verstaan het dan is dit duidelik dat ook die toetrede tot die amp nie primêr op 'n suiwer menslike keuse berus nie. Die vadere is dit dan ook met mekaar eens dat ' $n$ goddelike roeping aan die dienswerk in die kerk vooraf moet gaan. Juis omdat die amp ' $n$ instelling van God is ten behoewe van die kerk en nié ' $n$ instelling van die kerk self nie spreck dit van self dat dit God sal wees wat roep, wat bekwaam maak tot die amp, wat self stuur en gebruik. Dit is juis in ons dae, met sy vervlakkende tendense, noodsaaklik om te besef dat die amp, as roeping van God, eindeloos meer is as ' $n$ pos of ' $n$ funksie in en van die kerk waarmee na willekeur gehandel kan word.

As Luther oor die roeping tot die amp handel, dan beklemtoon hy cit dat alle gelowiges deur die doop geroep is tot ' $n$ algemene priesterskap met priesterlike regte en pligte. Die roeping tot die openbare amp is egter addisioneel, ' $n$ vocatio specialis. Omdat die amp nié voortkom uit die behoefte of die wil van die gemeente nie maar ' $n$ gawe van God aan die kerk is, daarom is die vocatio specialis ook nie ' $n$ instelling van die mens nie maar dit geskied iure divino. God het die roeping van mense tot die amp gebied..$^{33}$ )

Omdat Luther dit beklemtoon dat die amp suiwer funksioneel is, beteken die vocatio specialis vir hom terselfdertyd 'n positiewe beroep na ' $n$ bestaande gemeente waar die ampswerk gedoen kan word. Hier onderskei hy in die vocatio immediata en die vocatio mediata. Beide is ' $n$ goddelike roeping tot die amp. Die beroep deur die kerk of die gemeente is vir Luther egter altyd 'n roeping deur mense en nie vanweë mense nie. Die mense, die ander apsdraers dus, wat by die beroep optree is niks meer as werktuie van God wat sy wil doen nie. Die argument is duidelik: die amp is deur Christus ingestel en dit is sy wil dat die amp deur ' $n$ besondere roeping gevul sal word. Die hele roeping - beroep struktuur word deur Luther baseer op Mt. 18:19-20. Daarom stel hy dat die roepingshandeling in die kerk deur die gebed bepaal moet word want so word die goddelike karakter daarvan beklemtoon. ${ }^{34}$ ) Dit is dus iets anders as ' $n$ demokratiese verkiesing waar die meerderheid tegnies altyd reg is en die waarheid besit. Vir die ampsdraer self is die wete dat hy deur God self geroep is en in die amp gestel is ' $n$ voortdurende bemoediging. Hierdie sekerheid vind juis sy grond in die vocatio externa deur die gemeente.

By Melanchton kom grotendeels dieselfde momente na vore. Om tot die amp te kan toetree, het die gelowige primêr ' $n$ opdrag

33) Hiervoor beroep Luther hom op Rom. 10:15. Vgl. ook sy opmerking in 'n preek oor Op. 13:1 van 1524: Scitis quod nemo in cause dei agere debet, nisi sit vocatus et ordinatus a Deo, ut possit secura conscientia dicere: Certus sum hoc deum velle et hoc me agere, alioqui non exequatur neque consistet neque wirt im gelingen.

34) Oor wie die beroep moet uitbring en hoe dit presies moet geskied het Luther ook gehandel maar dit is vir die doeleindes van hierdie argument nie primêr ter sake nie. 
van God nodig. God moet, volgens Rom. 10:15 roep en indien die roeping nie bestaan nie, geld die oordeel van Jer. 23:21. Dié goddelike roeping moet egter opgevoig word deur 'n openbare beroep tot die amp in die gemeente. In die Confessio Augustana, art. 14 stel Melanchton:

„Niemand darf in der Kirche öffentlich lehren oder die Sakramente verwalten, er sei denn dazu recht mäszig berufen."

Ook die beroep is 'n goddelike opdrag want God wil geen barbaricae confusiones in die kerk toelaat nie en dié sal ontstaan as elke gelowige, sonder 'n spesifieke beroep, die openbare amp sou begin uitoefen. Alleen deur 'n externa vocatio met sigbare testimonia kan sowel die ampsdraer as die kerk seker wees dat dit God is wat gestuur het en opdrag gegee het.

Melanchton onderskei ook in die vocatio immediata en 'n vocatio mediata en stel dat in beide gestaltes die subjek van die roeping die drieënige God is. Die vocatio immediata het egter, na die profete en apostels, uit die kerk verdwyn en die enigste geldige roeping wat nog voorkom, is die vocatio mediata. In hierdie geval word die ampsdraer deur die suffragatio humanae beroep tot 'n spesifieke diens in die kerk. Alleen as die geroepene so in die amp gestel is, kan daar seën op sy arbeid wees. ${ }^{35}$ )

Martin Bucer neem hier grotendeels die terminologie van Luther oor en beklemtoon ook dat die vocatio specialis 'n saak van God self is. ${ }^{36}$ ) As die kerk beroep, is dit slegs die aanvaarding van die roeping van God wat aan die beroep moet voorafgaan. Die vocare is die eksklusiewe reg van die heer van die kerk en die kerk kan slegs agnosci, considerare inquirere. God is dit wat designat. ${ }^{87}$ ) Met die beklemtoning van die goddelike roeping word die verantwoordelikheid van die ampsdraer teenoor God beklemtoon en word dit duidelik dat die ampsdraer geroep word om in die midde van die gemeente die Woord van God te dien en te bedien.

Tog handel die gemeente ook in hierdie saak want hoewel God roep, kan die gemeente vasstel of dit werklik so is voordat hulle die ampsdraer aanvaar. Daarom wys Bucer op die uiterlike tekens waaraan die geroepenheid deur God meet kan word $\mathrm{nl}$. die bekaamheid, die wil en die geleentheid. ${ }^{38}$ ) Die goddelike roeping is dus nie 'n verborge roeping nie maar kan vasgestel word en so handel die gemeente tog in gehoorsaamheid aan God wat vrymagtig roep wie Hy wil.

By Calvyn word nie veel aandag gegee aan wat hy die inwendige roeping noem nie omdat dit feitlik onmoontlik is om die innerlike van ' $n$ mens te kontroleer. Tog stel Calvyn dat die inwendige roeping

35) H. Lieberg, a.a.O., S. 314 f.

36) W. van 't Spijker, a.w., bl. 367.

37) W. van 't Spijker, a.w.r bl. 368.

38) W. van 't Spijker, a.w., bl. 369. 
alleen dan werklik is as dit deur 'n uitwendige roeping of beroep opgevolg word. ${ }^{39}$ ) Daar moet dus 'n kerklike beroep volg op die inwendige roeping deur die Heilige Gees.

Net soos Bucer sien Calvyn dat die voornemende ampsdraer wel ' $n$ uiterlike teken van die roeping moet vertoon..$^{40}$ ) God wys nooit ' $n$ ampsdraer aan sonder om hom van die nodige genadegawes te voorsien nie en aan die genadegawes van die Gees kan geoordeel word of hy werklik deur God geroep is. ${ }^{41}$ ) Calvyn is dan ook baie stellig dat niemand sonder hierdie genadegawes bevestig mag word nie. Die hoop dat die ampsdraer dalk later, nadat hy reeds in die amp gestel is, die nodige genadegawes mag ontvang, word deur Calvyn afgewys. ${ }^{42}$ ) Merkwaardig genoeg, noem Calvyn net twee genadegawes van die Gees wat nodig is vir die amp van dienaar van die Woord $\mathrm{nl}$. die suiwere leer en die vrome lewenswandel.43) Hier moet die bevoegde ampsdraers baie sorgvuldig oordeel ter wille van die welsyn van die kerk. ${ }^{44}$ ) Ook by Calvyn is dus die goddelike roeping ' $n$ voorwaarde vir die amp en word ook hier duidelik dat die amp primêr' $n$ gawe van God aan die kerk is en nie 'n saak wat uit die kerk self na vore gekom het nie.

Uit die voorgaande is dit wel duidelik hoe grondig die amp in die reformatoriese kerke na die eis van die Skrif alleen hervorm is. Juis die beklemtoning van die goddelike roeping van die amp, die hoë waarde van die amp en die groot eise wat aan die ampsdraer gestel word, het meegebring dat die reformatoriese predikante, oral waar hulle geleef en gewerk het, inderdaad in staat was om die kerk op te hef, die ewige redding van mense te bewerkstellig, die wêreld te herstel en die koninkryk van God en Christus weer op te rig. ${ }^{45}$ )

In ons tyd word daar baie vrae oor en rondom die amp gestel. Die groot vraag is egter of in die gesprek nie te veel uit die oog verloor word dat God self die amp ingestel het ten behoewe van die kerk en dat Hy self mense roep om, as werktuie in sy hand, die evangelie van Jesus Christus te verkondig tot redding en tot opbou van die kerk nie. Die amp, soos die vadere dit gesien het, is ' $n$ goddelike roeping wat hoë eise aan die sondige mensekind stel om oral en altyd en in alle omstandighede die Woord van God alleen te verkondig in reslose gehoorsaamheid aan die hoof en heer van die kerk. Roepingsbesef, toewyding en diensbaarheid aan God, getrouheid en volhardende ywer in die dienswerk van die Woord is die hoë eise wat die vadere aan die dienaar van die Woord gestel het. As ons die geskiedenis van daardie tyd bestudeer, sal ons sien dat hulle, in ieder geval, nie tekortgeskiet het nie.

\footnotetext{
39) Joh. Calvinus, Comm. Jer. 23:21 en I Tim. 4:14.

40 Joh. Calvinus, Comm. Jes. 61:1.

41 Joh. Calvinus, Comm. I Kor. 12:28 en Lk. 4:18.

42 Joh. Calvinus, Comm. Lk. 5:10.

43 Joh. Calvinus, Inst. IV. 3. 12.

44 Joh. Calvinus, Cormm. Hand. 6:3.

45) Joh. Calvinus, Comm. I Thess. 5:12.
} 